\title{
Deformite cerrahisinin geleceği
}

\author{
The future of the deformity surgery
}

\author{
Melih Civan ${ }^{1}$, Levent Eralp ${ }^{2}$
}

\author{
${ }^{1}$ Gaziosmanpaşa Eğitim ve Araştırma Hastanesi, Ortopedi ve Travmatoloji Kliniği, İstanbul \\ ${ }^{2}$ İstanbul Üniversitesi, İstanbul Tıp Fakültesi, Ortopedi ve Travmatoloji Anabilim Dalı, İstanbul (Emekli Öğretim Üyesi)
}

\begin{abstract}
Deformite cerrahisi, ortopedinin en zorlu alt uzmanlık dallarından birisidir. Eksternal fiksatör, intramedüller çivileme, yumuşak doku rekonstrüksiyonu, travma cerrahisi gibi bir çok farklı uygulama alanının temel prensiplerinin birleşimi ile meydana gelmiştir. Ancak distraksiyon osteogenezinin keşfi ile deformite cerrahisi dünyada hızla popülarize olmuş, gelişmiş ve yaygınlaşmıştır. Her bilimsel keşfin arkasında olduğu gibi, deformite cerrahisinin de bir hikâyesi vardır. Bu hikâye kimi zaman başarılı bilim insanlarını, kimi zaman teknolojiyi, kimi zaman değişen felsefe ve yaklaşımları içerir. Bu makalede, deformite cerrahisinin, yükselişi, ortopediye nasıl yön verdiği ve gelecekte nasıl şekilleneceği tartışılmaktadır.
\end{abstract}

Anahtar sözcükler: deformite cerrahisi; tarih; rekonstrüksiyon; ilizarov
Deformity surgery is one of the toughest subspecialities of orthopaedic surgery. It contains the combination of many different principles such as external fixation, soft tissue reconstruction, intramedullary nailing and trauma surgery. The discovery of distraction osteogenesis was popularized the deformity surgery and augmented and spread it to the world. It has its own story like any other scientific discovery. This paper includes many devoted scientists, technology, philosophy and approaches from time to time. In this article, the evaluation, impaction and prediction of the deformity surgery will be discussed.

Key words: deformity surgery; history; reconstruction; Ilizarov

seyahatler ile bilgiyi dünyanın çeşitli bölgelerine dağıtıyor, basılı yayıncılık ile uzun zahmetler sonucunda tıp literatürü yeniden hayata dönüyordu. İkinci dünya savaşının yarattığı kutuplaşma 1921 yılında doğmuş ve hayatını 'Demir Perde'nin arkasında geçirmiş bir mucidin icatlarının ve felsefesinin dünyaya yayılmasını çeyrek yüz yıl geciktirecekti. Bazı yazarlar Gavril Abramoviç ilizarov'dan önce distraksiyon osteogenezinin keşfedildiğini ve kullanıldığını dile getirseler de, illizarov'un o günün şartlarında akademik ziyaretler yapmaktan çok, gelen bilim adamlarına ev sahipliği yaptığı bir gerçektir ${ }^{[2]}$.

İlizarov'un dünyaya armağan ettiği "distraksiyon osteogenezi", yarım asır önce Bologna'da Codivilla ve ögrencisi Putti tarafından daha basit tekniklerle uygulanmıştı. Sınırlı sayıda cerrahın bu elli yıl içerisinde aynı doğrultuda araştırmaları mevcuttur. Bu sebeple ilizarov'un distraksiyon osteogenezini keşfettiği bilgisinin bir yanlış idrak etme olduğunu söylemek, bir nehrin yatağını insan eliyle değiştirmeye benzemektedir.

- Illetişim adresi: Op. Dr. Melih Civan, Karayolları Mahallesi, Osmanbey Caddesi, 621 Sokak, Gaziosmanpaşa / İstanbul

Tel: 0212 - 9453000 e-posta: melihcivan@gmail.com

- Geliș tarihi: 21 Kasım 2019 Kabul tarihi: 4 Aralık 2019 
Çünkü ilizarov sadece bir implant setini icat etmekle kalmayıp, felsefesini, çeşitliliklerini, sonuçlarını somut kanıtlarla aydınlatmış, isimlendirmiş ve bütün zorluklara rağmen dünyaya sonunda haykırabilmiştir. Bir mucit, hekim ve akademisyen olarak farklı hikâyelerin bir bütününe sahiptir. Kendi ülkesinde bile zorlukla kendini ifade edebilmiş, döneminde savaşların yerini alan spor müsabakalarının yıldızlarından Valery Brumel'in tedavisi ile bütün Asya Kıtası'nda tanınmıştır ${ }^{[3]}$.

Valery Brumel'in desteği ile ünü gittikçe artan ílizarov'un dünyada tanınmasına ise bir gezgin ön ayak olmuştur. Antropolojik araştırmalar için yaptığı okyanus ötesi yolculuklarında oluşturduğu uluslararası ekip, Thor Heyeldal'ın bu hikâyede önemli ancak geç farkına varılan bir rolü olduğunu göstermektedir. Çünkü İtalyan dağcı, fotoğrafçı ve gezgin Carlo Mauri, Heyeldal'ın yaptığı ikinci gezide psödoartroz tedavisinin dünyada farkIı yıllarda yaşandığını öğrenmiş ve sonunda Kurgan'ın tedavi ettiği hastalardan biri olmuştur. 1986'daki AO konferansında davetli bir konuşmacının, dünya mirası olarak nitelendirdiği enstrümanlarının, Rusya'dan İtalya'ya hediye edilmesini bir tesadüf olarak görmek, tarihsel bir bakış açısı olamaz. Yoksa dünyada bu keşfi ve felsefeyi ilk tanıtan Oldrich Cech olurdu ${ }^{[4]}$.

Tam bu noktada Türkiye Cumhuriyeti'nde de "Prometheus"ların varlığı ateşin İstanbul'a kadar sıçramasında büyük rol oynamıştır. 1983 yılında, Paley'in illizarov'un gözlemcisi olmasından üç yıl önce İstanbul Tıp Fakültesi'nde Mehmet ÇAKMAK, okuduğu gazete haberinden ateşi takip etmeye karar verdi. ilk kez 14 yaşında bir hastaya, 1984 yılında epifiz distraksiyonu yapmayı planladı. 1985'teki Mersin Ulusal Ortopedi Kongresi'nde bu olguyu sundu. 1987 yılında ise epifiz distraksiyonu yerine kallus distraksiyonu uygulamalarına başladı. 1988'de ise ilizarov'u Türkiye'ye davet ederek, bir konferans vermesini sağladı ${ }^{[5,6]}$.

Dünyada ortak akıl ve bilim bir çok farklı dillerde ve kültürlerde yaşansa da, iletişime duyulan muazzam ihtiyaç bizleri ortak lisan kullanımına zorlamaktadır. Bilimin bu isteğinde haklı sebepleri vardır. Ayak uydurmak zorunda olduğumuz bir gerçekle karşı karşıyayız. Çağdaş meslektaşlarından çok daha önce adım atmış öncü bilim insanlarının bugün yeteri kadar öne çıkarılamamasında "lisan" çok önemli bir role sahiptir. Paley'in 1989 yılında yayımladığı “Limb Lengthening” makalesi, halen dünyanın en çok atıf alan bilimsel yazılarından biridir[7], çünkü günümüz ortak tıp lisanında yazılmıştır. Bu şekilde yazılı eserleri üretmekte geç kalsak da, ekstremite rekonstrüksiyonu ve deformite cerrahisinin bütün önemli ameliyatlarını içeren, neredeyse bütün tekniklerin örnek olgularına sahip bir arşiv bugün İstanbul Üniversitesi, İstanbul Tıp Fakültesi'nde bulunmaktadır. Bu arşivdeki yaklaşık üç bin olgu, yirmi yıllık özverili bir çalışmanın eseri ve bu kurumdan yetişmiş bir çok bilim insanının hikâyesini anlatmaktadır.

Günümüzde "ilizarov Metod ve Prensipleri" ile deformite cerrahisi, hala popülerliğini ve gerekliliğini korumaktadır. Ancak, bilimsel ilerleme ve değişim, implantolojide çeşitlilikler ve kombine teknikleri doğurmuştur. Sirküler fiksatörler ile intramedüller implantların uzun birlikteliği, otomatize çivilerin yaygınlaşmasına kadar başarılı bir geçiş tekniği olarak literatüre girmiştir. Distraksiyon osteogenezinin etkili kullanımının korunmasına rağmen, transfiksasyonun süresinin ve yaygınlığının azaltılması modern uzatma ve rekonstrüksiyon yöntemlerinin gelişiminde en önemli hedeflerden biridir. Özellikle konjenital deformitelerde ve pediyatrik popülasyonda implant boyutu ve transfiksasyon büyüklüğü cerrahi başarısını etkilemektedir. Kemik enfeksiyonlarında ise her geçen gün daha karmaşık mikroorganizmalar ile daha güçlü antibiyotikler savaş halinde olsa da, geleneksel tabiri ile "ilizarov'un ateşine" hala ihtiyaç duyulmaktadır ${ }^{[8,9]}$.

Geçmişten günümüze bütün bu gelişmeler ortopedi enstrümanlarının araştırma ve geliştirme çalışmalarına yön vermektedir. Yumuşak dokuya daha saygılı cerrahiler için minimal invaziv implantlar daha sık karşımıza çıkmaktadır. Üç boyutlu yazıcılar ile hastalara özel önceden tasarlanmış implant kullanımı, tıpkı tümör cerrahisinde ya da artroplastide kullanıldığı gibi ekstremite rekonstrüksiyonunda da kullanılmaktadır. Diğer yandan mevcut implantların geliştirilmesi ve kullanım alanlarının genişletilmesi hedeflenmektedir. Günümüzde uzayabilen plaklar halen geliştirme aşamasındadır. İntramedüller çivilerde elde edilen teknoloji, jukstakortikal bölgede kullanılacak implantlara dâhil edilmek istenmektedir. İlk denemeleri büyük serilerde başarıya ulaşmasa da eninde sonunda bu teknolojiye ulaşılacağı beklenmektedir. Uzatma cerrahisinde ise geçen beş yılın araştırma konularının başında tam yük tolerasyonu olan ve implante edilebilen intramedüller çiviler yer almaktadır. Uzatma cerrahisinin günümüzde daha kozmetik ve başarılı uygulanmasında anahtar role sahip olan uzayabilen çivilerde, daha kalın kilitleme vidaları ve dayanıklı biyomalzemeler ile yeni nesil çivilere ulaşılmıştır. Bu intramedüller çivilerde tam yük vererek, geçici iş gücü kaybının önüne geçilmesi ve metabolik stimülasyonun uzatma süresini kısaltması hedeflenmektedir. Uzayabilen çiviler intramedüller kaviteye çivi yerleştirilmesinin uygun olmadığı durumlarda, internal-eksternal fiksatör olarak kullanılmaktadır. Yüksek (proksimal) tibial osteotomi ya da amputasyon güdük uzatma cerrahilerinde uzayabilen çivi kullanımı ya da bu implantların kontrol ünitelerinin cep telefonu uygulamaları kadar ulaşılabilir olması ise günümüzün heyecan verici ve ilginç gelişmeleridir ${ }^{[10]}$. 


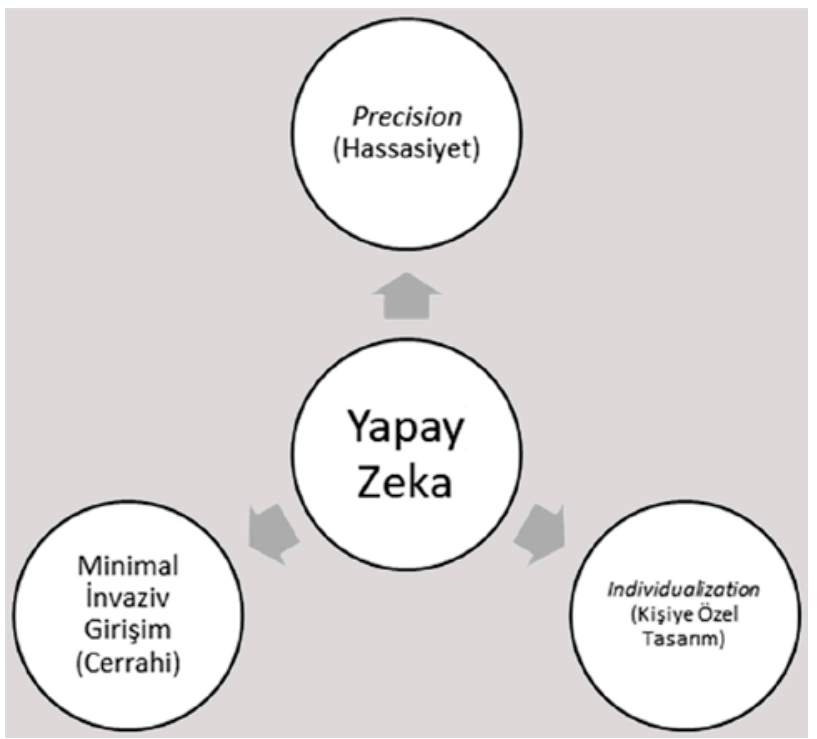

Şekil 1. Ekstremite rekonstrüksiyonunda gelecekten beklentilerin, yapay zekâ ile yönetilen, hassas, kişiye özel ve minimal invaziv girişimler doğrultusunda gelişmesi beklenmektedir.

Rekonstrüksiyon implantlarının günümüzde çarpıcı kullanım alanlarına örnek olarak travma da verilebilir. Ekonomik sıkıntılarını geride bırakmış bir takım ülkelerde acil travma ünitelerinde bilgisayar destekli fiksatörler birincil kırık tespiti için kullanılmaktadır. Basit tübüler fiksatörler kadar hızlı ve sonrasında çerçeve modifikasyonuna izin verecek tespitlerin ilk bilimsel verileri yayımlanmıştır ${ }^{[11]}$. Otomatize çiviler ise distraksiyon yerine kompresyon yapılarak, kaynama etkinliğinin arttırılması ve daha minimal invaziv cerrahi avantajı sebebi ile travma cerrahisinde kullanılmaya başlanmıştır. Otomatik uzayan çivilerin, klasik travma çivileri kadar yaygınlaşmasının önünde şu an sadece ekonomik sebepler yer almaktadır. Ülkemiz için halen uzayabilen intramedüller çivi kullanımı çok maliyetli olmakla birlikte, tıpkı bilgisayar destekli fiksatörlerin yaygınlaştığı gibi gelecekte bu implantların da yaygın ve düşük maliyetlerle kullanılması beklenmektedir.

Ekstremite rekonstrüksiyonu teknik ve teknolojisinin gelişmekte olduğu 21. yüzyılda önemli gelişmelerden birisi de ortopedi ve travmatoloji uzmanlarının Ortopedik Rehabilitasyona olan bakış açısıdır. Fizik tedavi ve rehabilitasyonun cerrahinin başarısına etkisi literatürde gittikçe daha baskın hale gelmektedir. Ortopedik rehabilitasyonun ve ekstremite kas dengesinin daha iyi anlaşılması sonucunda, uzatma cerrahileri yerine kısaltma cerrahisinin yapıldığı tedavi yöntemleri ortaya çıkmış$\operatorname{tır}^{[9]}$. Başarılı fizik tedavi ile günümüz cerrahi morbiditelerinde kayda değer düşüşler yaşanmakta ve hem hasta hem de cerrah memnuniyetini artırmaktadır.
Zamanın ve teknolojinin ilerlemesi, insan zekâsının ve 'derin öğrenme' teknikleri ile yapay zekanın, çok kısa bir gelecekte, tedavi planlamasının merkezine yerleşeceğini söylemek bir hayal olmaz. Tabii ki deformite düzeltmenin biyolojik, mekanik ve geometrik prensipleri asla değişmeyecektir, tıpkı Newton'un ya da termodinamiğin ilk üç kanununun asla değişmeyeceği gibi. ilk tarif edildiklerinde basit kaldıraçları tarif eden bu kanunlar, günümüzde uzayda madde değişimini tarif etmek için kullanılmaktadır. Aynı şekilde deformite düzeltme prensiplerini temel alan yapay zeka (artificial intelligence) merkezli bilgisayar programları ve üretim platformları; kişiye özel, kılı kırk yaran hassasiyette, ve bedene en az zarar veren (minimal invaziv) teknik ve teknolojiler oluşturarak, deformite cerrahisinin önümüzdeki çeyrek yüzyılını ortaya koyacaklardır. Yirmi birinci yüzyılın ikinci yarısını ise, henüz hiç bilemediğimiz paradigmalar tarif edecektir. Sonuçta her alanda olduğu gibi deformite ve ekstremite rekonstrüksiyonu cerrahisi de bilime ayak uydurmaya, değişmeye ve evrilmeye devam edecektir. Hastalara daha faydalı, daha az zarar veren tedavi yöntemleri, teknoloji ve teknik ilerlemeler ile daha ileri bir noktaya taşınacaktır. Bu yolculuğa farklı zamanlarda dahil olmuş, tanıklık yapmış ve hala yapmakta olan, zaman zaman katkıda bulunan bizlerin ise en önemli görevi, bilginin sürekliliği ve gelişmesinin devam etmesini sağlamak ve onu gelecek kuşaklara aktarmaktır. Tıpkı Fabricus'tan Harvey'e, Covilla'dan Putti'ye, Hunter'dan Cooper'a, Paget'den Virschow'a ya da Da Vinci'den Melci'ye aktarıldığı gibi... 


\section{KAYNAKLAR}

1. Ponseti IV. History of orthopaedic surgery. lowa Orthop j 1991;11:59-64. Crossref

2. Paley D. The Ilizarov technology revolution: History of the discovery, dissemination, and technology transfer of the Ilizarov method. J Limb Lengthen Recon 2018;4(2):115-28. Crossref

3. Birch JG. A brief history of limb lengthening. J Pediatr Orthop 2017;37:S1-8. Crossref

4. Cech O, Marti RK. Evolution of treatment of nonunions. In: Marti RK, Kloen P, editors. Concept and Cases in Nonunion Treatment. Thieme; 2011. p.11-29.

5. Eralp L. History and phylosophy of ilizarov's method. In: Basic Principles of Deformity Correction. Çakmak M, Şen C, Eralp L, Balcı HI, Civan M, editors. Switzerland: Springer; 2016. pp.3-10.
6. Çakmak M. Personal communication, İstanbul; 2013.

7. Paley D. Current techniques of limb lengthening. J Pediatr Orthop 1988;8(1):73-92. Crossref

8. Kocaoglu M, Bilen FE, Sen C, Eralp L, Balci HI. Combined technique for the correction of lower-limb deformities resulting from metabolic bone disease. J Bone Joint Surg Br 2011;93-B(1):52-6. Crossref

9. Paley D. Surgical reconstruction for fibular hemimelia. J Child Orthop 2016;10(6):557-83. Crossref

10. Green SA, Dahl MT. The Future of Intramedullary Limb Lengthening. In: Intramedullary Limb Lengthening -Principles and Practice. Cham: Springer; 2018. pp.171-83. Crossref

11. Kara A, Çelik H, Seker A, Karakoyun O, Armagan R, Kuyucu E, Erdil M. Treatment of open fractures with a computerassisted external fixator system without the use of fluoroscopy. J Orthop Surg Res 2016:11(1):51. Crossref 